\title{
Payments for watershed ecosystem services in the Miringuava basin, Brazil: Mediating or exacerbating conflicts in peri-urban commons?
}

\author{
(iD) Niklas Werner Weins ${ }^{1}$ (Deticia Costa de Oliveira Santos ${ }^{2}$ (D) Manuela Dreyer Silva $^{3}$ \\ iD Tatiana Gadda ${ }^{4}$ (D) Christian Luiz da Silva ${ }^{4}$ \\ ${ }^{1}$ MA; University of Campinas, Brazil.weinsniklas@gmail.com \\ ${ }^{2}$ MA; Federal University of ABC, Brazil. Icos.leticia@gmail.com \\ ${ }_{3}^{3}$ PhD; Federal University of Paraná, Brazil. leladreyer@yahoo.com.br \\ ${ }^{4}$ PhD; Federal University of Technology - Paraná, Brazil. tatianagadda@utfpr.edu.br \\ ${ }^{5}$ PhD; Federal University of Technology - Paraná, Brazil.christianlsilva76@gmail.com
}

Cite as

American Psychological Association (APA)

Weins, N. W., Santos, L. C. de O., Silva, M. D., Gadda, T., \& Silva, C. L. (2021, Special Issue, April). Payments for watershed ecosystem services in the Miringuava basin, Brazil: Mediating or exacerbating conflicts in periurban commons? J. Environ. Manag. \& Sust., 10, 1-24, e18468. https://doi.org/10.5585/geas.v10i1.18468.

\begin{abstract}
Objective: This article addresses institutional arrangements and participation issues in the case study of a commons dilemma in the peri-urban sphere. It aims to evaluate the institutional robustness according to Ostrom's eight design principles of a Payments for Ecosystem Services (PES) arrangement in the Miringuava River Basin, São José dos Pinhais, Brazil.

Methodology: Using documentary analysis, and semi-structured interviews with stakeholders we analyze the applicability of Ostrom's eight design principles.

Relevance: Our analysis and discussion shed light on social and institutional dimensions that might be insufficiently considered by the local public administration.

Results: While our analysis showed that most principles apply in some measure to the case study, favoring the implementation of PES, there are divergences in terms of monitoring, conflict resolution, and sanctions that hint to particular problems of peri-urban commons management. We conclude that PES could become a problem of collective action, representing a mechanism to increase robustness of peri-urban institutions, which allowed us to interpret ES as a common.

Theoretical contributions: The PES for forest areas, has run parallel to an agricultural transition to organic farming desired by environmental organizations but resisted by local farmers. While the conservation is justified by the reduction of water treatment costs and an increase in water availability, social implications of this choice turn out to be much more complex.

Management contributions: There is a need for the creation of institutional arrangements that consider power imbalances and to expand the different forms of participation in the situated action arenas created for governance and management of a common.
\end{abstract}

Keywords: Common pool resource management. Institutional robustness. New institutional economics. Environmental policies. Watershed management.

\section{Pagamentos por serviços ambientais hídricos na bacia do Miringuava, Brasil: Mediando ou exacerbando conflitos em comuns periurbanos?}

\section{Resumo}

Objetivo: Este artigo aborda arranjos institucionais e questões de participação em um estudo de caso de um dilema de comuns na esfera periurbana. Visa avaliar a robustez institucional de acordo com os oito princípios de design de Ostrom em um arranjo de Pagamentos por Serviços Ambientais (PSA) na Bacia do Rio Miringuava, São José dos Pinhais, Brasil. 
Metodologia: Utilizando análise documental e entrevistas semi-estruturadas com partes interessadas, analisamos a aplicabilidade dos oito princípios de design de Ostrom.

Relevância: Nossa análise e discussão esclarecem dimensões sociais e institucionais que podem ser insuficientemente consideradas pela administração pública local.

Resultados: Embora nossa análise tenha mostrado que a maioria dos princípios se aplica ao caso, favorecendo a implementação de PSA, existem divergências em termos de monitoramento, resolução de conflitos e sanções, apontando para problemas particulares de gestão de comuns periurbanos. Concluímos que PSA pode se tornar um problema de ação coletiva, representando um mecanismo para aumentar a robustez das instituições periurbanas, permitindo interpretar o Serviço Ambiental como um comum.

Contribuições teóricas: O PSA para conservação de áreas florestais ocorre paralelamente a uma transição para agricultura orgânica desejada pelas organizações ambientais, mas resistida pelos agricultores locais. Embora a conservação seja justificada pela redução dos custos de tratamento de água e pelo aumento da disponibilidade hídrica, as implicações sociais desta escolha revelam-se muito mais complexas.

Contribuições para a gestão: Existe a necessidade de criação de arranjos institucionais que considerem os desequilíbrios de poder e que ampliem as diferentes formas de participação nas arenas de situação-ação criadas para governança e gestão de um bem comum.

Palavras-chave: Gerenciamento de recursos comuns. Robustez institucional. Nova economia institucional. Políticas ambientais. Gerenciamento de bacias hidrográficas.

\section{Pagos por servicios ambientales hídricos en la cuenca del Miringuava, Brasil: ¿Mediando o exacerbando los conflictos en los bienes comunes periurbanos?}

\section{Resumen}

Objetivo: Este artículo aborda los arreglos institucionales y cuestiones de participación en un estudio de caso de un dilema de bienes comunes en el ámbito periurbano. Su objetivo es evaluar la solidez institucional según los ocho principios de diseño de Ostrom de un acuerdo de Pagos por Servicios Ambientales (PSA) en la cuenca del río Miringuava, São José dos Pinhais, Brasil.

Metodología: Mediante el análisis de documentos y entrevistas semiestructuradas con las partes interesadas, analizamos la aplicabilidad de los ocho principios de diseño de Ostrom.

Relevancia: Nuestro análisis y discusión aportan datos sobre dimensiones sociales e institucionales que pueden ser insuficientemente consideradas por la administración pública local.

Resultados: Aunque nuestro análisis demostró que la mayoría de los principios se aplican al caso, favoreciendo la aplicación del PSA, existen divergencias en cuanto a la supervisión, la resolución de conflictos y las sanciones, lo que apunta problemas particulares de la gestión de los bienes comunes periurbanos. Concluimos que el PSA puede convertirse en un problema de acción colectiva, representando un mecanismo para aumentar la robustez de las instituciones periurbanas, permitiendo interpretar el Servicio Ambiental como un bien común.

Aportes teóricos: EI PSA para la conservación de los bosques se produce en paralelo a una transición a la agricultura ecológica deseada por las entidades ecologistas pero a la que se resisten los agricultores locales. Mientras que la conservación se justifica por la reducción de los costes de tratamiento del agua y el aumento de su disponibilidad, las implicaciones sociales de esta decisión resultan ser mucho más complejas.

Aportes a la gestión: Es necesario crear arreglos institucionales que tengan en cuenta los desequilibrios de poder y amplíen las diferentes formas de participación en los escenarios de situaciónacción creados para la gobernanza y la gestión de un bien común.

Palabras clave: Gestión de recursos comunes. Robustez institucional. Nueva economía institucional. Políticas ambientales. Gestión de cuencas hidrográficas.

\section{Introduction}

A Common-Pool Resource (CPR) is defined as a resource shared by a group of individuals that shape its patterns of access, use and reproduction (Ostrom, 1990; Ostrom et al., 1994; Ostrom, 1999). The concept has evolved over time, incorporating new theoretical 
and practical (Berkes, 2006; Cox et al., 2010) as well as interdisciplinarity perspectives (Castro, 2017). Embedded in these perspectives are approaches that add to the discussion regarding the rules for the use of commons (McGinnis \& Ostrom, 2014) and their institutions, the so-called Institutional Analysis and Development (IAD) framework.

In collective action related to CPR, balanced costs and benefits are not necessarily expected: some resource users will benefit after all costs are considered, while others will suffer net losses (Ostrom, 2008). Institutional choices are made, and the gains and losses are monitored and evaluated in accordance with possible changes in the arrangements of these collective action arenas. From the perspective of institutional analysis, Ostrom's work (1990) initiates the discussion on principles that characterize the robustness of these institutions in complex systems, such as water supply. There are eight principles (Ostrom et al., 2002) that evaluate the contribution of institutions to the sustainability of resources in common use: welldefined user and resource boundaries; balanced costs and benefits in collective action; collective decision-making arrangements; a system for monitoring; graduated sanctions; conflict resolution mechanisms; minimal recognition of local institutions; and nested enterprises.

The design principles are a tool that helps explain the conditions under which "trust and reciprocity can be built and maintained to sustain collective action in the face of social dilemmas posed by CPR" to prevent their deterioration (Cox et al., 2010, p. 39). In the discussion of the robustness of a system, Ostrom (1990) shows that such principles are not static conditions and, therefore, implementing innovation processes that ensure cooperative behavior in collective action is possible. Recent research shows that water management can be discussed through the lens of institutional theory. Such a framework allows for studying governance systems that influence the performance of institutions and different actors' behavior and actions (Adeoti, 2019; Afroz et al., 2016).

In this sense, this article addresses questions about the institutional arrangement and the participation in commons dilemmas (collective action) of a peri-urban system. The main innovation was the introduction of Payments for Ecosystem Services (PES) as a solution to promote the conservation of a basin for the common good of the city.

Peri-urban environments are particularly influenced by the "physical proximity of different land uses and related social, economic and physical processes". Thus, conflicts and environmental degradation may not be addressed without considering urban and rural dynamics (Allen, 2003, p. 146). In peri-urban areas, commons have multiple and often contested uses: a recreational place for wealthier urban strata can serve agricultural production functions and hold cultural significance for traditional populations (Mundoli et al., 2015). Therefore, synergies and trade-offs between urban and peri-urban processes as well 
as political and socioeconomic contexts should be considered in the planning and management of peri-urban environments (Allen, 2003).

As the discussion on commons in peri-urban interfaces expands, different aspects are highlighted. For example, impacts of urbanization linked to changes in social and ecological interactions in urban landscapes generate larger issues in terms of sustainability and equity, particularly in cities of the Global South (Clement, 2010; Mundoli et al., 2015). Especially in mid-sized cities, significant growth occurs in peri-urban areas (Ferreira et al., 2020). Peripheral areas usually offer lower costs and lighter regulations, with the possibility to conciliate urban and rural livelihoods - "the peri-urban interface is therefore highly mixed in terms of uses and also highly dynamic and unstable" (Watson, 2009, p. 184).

For Ostrom (1999), the protection of CPR has traditionally relied on collective action and the locals' ability to interact, requiring some degree of social capital. In peri-urban interfaces, social capital is usually generated from sharing land, livelihoods, history, and culture. Those aspects are jeopardized by urbanization, causing a decline in reliance on land, commons-based livelihoods, and disassociation of people from both (Mundoli et al., 2015). Allen (2003) emphasizes the importance of power relations in contexts of the Global South. Imbalances in social and economic impacts of environmental changes not only have outcomes "in terms of winners and losers," but also in altering power relations among actors and how responses to environmental issues are institutionalized (Allen, 2003, p. 146). The participation of the destitute in the negotiation of priorities and decision-making influences the capacity of environmental planning and management to benefit them effectively (Allen, 2003).

The main theoretical challenge in this case study lies in connecting the peri-urban context through an economic mechanism (PES). Bardhan (2000, p. 861) found that "cooperative behavior in an irrigation community is by and large significantly related negatively to urban or market connections". While PES are understood as voluntary transactions between "service users and service providers that are conditional on agreed rules of natural resource management for generating offsite services" (Wunder, 2015, p. 241), power and equity implications have only been marginally explored in the literature (Bakker, 2009; Kosoy \& Corbera, 2010; Paudyal et al., 2016; Hausknost et al., 2017).

Ecosystem Services (ES) are commonly defined as the benefits people obtain from nature. Therefore, it is essential not only to understand the service flows themselves but also their implications on the social fabric. Despite being a contested concept (Schröter et al., 2014), ES can be considered a helpful and practical communication tool to conceptualize human-nature relations (Partelow \& Winkler, 2016; Paudyal et al., 2016). Kolinjivadi et al. (2014, pp. 145-46) hold that the "governance of watershed goods and services involves management of the commons" and argue "it is the conceptualisation of nested institutions which frames the role that PES might play in (...) managing the watershed commons". Barton 
et al. (2017, p. 418) discuss how the IAD's rules-in-use conceptualization can help analyze PES as "economic, regulatory and informational instruments" within commons theory.

The logic of market mechanisms is often presented as an institutional innovation by replacing allegedly inefficient command-and-control policies with more efficient markets for ES (Gómez-Baggethun \& Muradian, 2015). However, several empirical and review studies have questioned this assumption and highlighted the importance of civil society and state action (Corbera et al., 2007; Schomers \& Matzdorf, 2013). Underlying social and labor aspects in ES production and the co-construction of environmental-institutional structures are often overlooked. Thus, it is fundamental to avoid one-sided interpretations of natural resources management choices and preferences (Kosoy \& Corbera, 2010; Ernstson, 2013; BerbésBlázquez et al., 2016).

This paper aims to test to which extent an ecosystem service (ES) can be considered a common. Following this rationality, our research question is to what extent PES can, in a broader sense, be considered a tool for inducing local management of a common in a periurban basin (Ostrom, 1990; 2005; McGinnis \& Ostrom, 2014). For this purpose, we tested the institutional robustness of the PES arrangement in the case study of the Miringuava River Basin in São José dos Pinhais (SJP), Paraná, Brazil, using the IAD framework. PES was introduced to promote the basin's conservation for the production of ES and, thus, for the common good of the city. With its characteristics and resulting conflicts, this is an emblematic case of a peri-urban space in which multiple CPR are under pressure from urbanization.

\section{Methodological procedures}

The methodology used in this research is rooted in the study of Science, Technology and Society and New Institutional Economics. It is applied to discussions about commons management dilemmas and PES. We used documentary analysis and semi-structured interviews as data collection methods (Harrel \& Bradley, 2009) and analyzed the results through the IAD framework's eight design principles for institutional robustness (Ostrom, 2008).

\section{Data collection and analysis}

The data for this research was obtained mainly from public documents and field data, including meeting memos, laws, and project reports, in addition to a socioeconomic database of the area by SEMA ${ }^{1}$. Data on urbanization and water was obtained from the Coordination of the Metropolitan Region of Curitiba (COMEC, 2006), the Integrated Supply System of Curitiba (SAIC), and the Basin Plan of the Upper Iguaçu Basin. Ecological and agricultural data were

\footnotetext{
${ }^{1}$ Paraná State Secretariat of the Environment and Water Resources
} 
drawn from SOS Mata Atlântica, the World Resources Institute and the local agricultural secretaries.

After a preliminary stakeholder analysis, contact with the involved stakeholders was obtained using the snowball method (Macnaghten, 2017) to confirm that all central stakeholders of the PES process were interviewed. Aiming to consolidate the final set of interviewed stakeholders as the intentional set of relevant actors, all respondents were asked to name the central stakeholders. From a total of 40 organizations named by the Municipal Secretariat of the Environment of SJP (SEMMA), 15 representatives responded. Ten were able to participate in personal interviews (30-180 minutes), while five used an online interface to respond to the same set of questions. The questionnaire was based on Zanella et al.'s material (2014), with four specific sections and five additional optional questions. The interviews were conducted between August and November 2018.

The key event for the discussion was the construction of the Miringuava dam, for which PES was established as a compensation mechanism. The dam's construction led us to further investigate the policy's conflict with the local farmer population. The IAD principles were discussed in the Management Group (MG) prior to the interviews. Before its application, the questionnaire was tested with three stakeholders and questions were clarified.

The questionnaire used open and multiple-choice questions to collect primary data about interviewees' general knowledge of PES and specificities of the Miringuava arrangement. Another objective was to understand differences among the involved actors. The multiple-choice part inquired about the applicability of the design principles according to each respondent (options: yes, partially, no). Through the open questions, participants could develop their assessment of the PES arrangement. This material was mainly used for content analysis.

Out of the 15 respondents, $40 \%(n=6)$ were female and $60 \%(n=9)$ male with an average age of 47,8 years (based on $n=12$ ). All participants self-declared as white, roughly representing the demographic profile of the region. However, it should be noted that this research selected an intentional and unrepresentative sample of the population.

The analysis was based on the data collected in the interviews to conduct a content analysis (Bardin, 2011), considering the eight design principles' categorical guidance to obtain more objective answers. We then analyzed the respondents' answers to the open questions to identify their position on conflicting issues. Finally, we triangulated data from the questionnaires, interviews and the public documents and news reports in our database. 


\section{Characterization of the study area}

The Miringuava basin lies in the Metropolitan Region of Curitiba (MRC), Brazil's eighthlargest city by population (3.2 million) (COMEC, 2017). Curitiba is known among Latin American cities for its early adoption of sustainability policies (Cassilha et al., 2020). The basin is located in the peri-urban context of the Brazilian Atlantic Forest, a highly diverse biome covering $15 \%$ of Brazil's territory, spanning 17 states. Only $12.4 \%$ of it is left, $80 \%$ of which are located in private areas (SOS Mata Atlântica, 2018).

Three municipalities in the MRC are executing PES pilots (Agência de Notícias do Paraná, 2014). Among them, the Miringuava basin in SJP is the most advanced one (Figure 1). The Miringuava river is an important tributary to the Upper Iguaçu, which also receives waters from the (strongly polluted) urban rivers of Curitiba. The drivers stressing the ecological systems within this peri-urban setting (Allen, 2003) include urban expansion of $<20 \%$ for SJP, the highest in the MRC (COMEC, 2006, p 182). Despite the solid urban growth, agricultural interests often dominate the political process in Paraná, a traditional agricultural state, which grew in the context of coffee and later soy-related agroindustries.

Figure 1 - Map of the study area
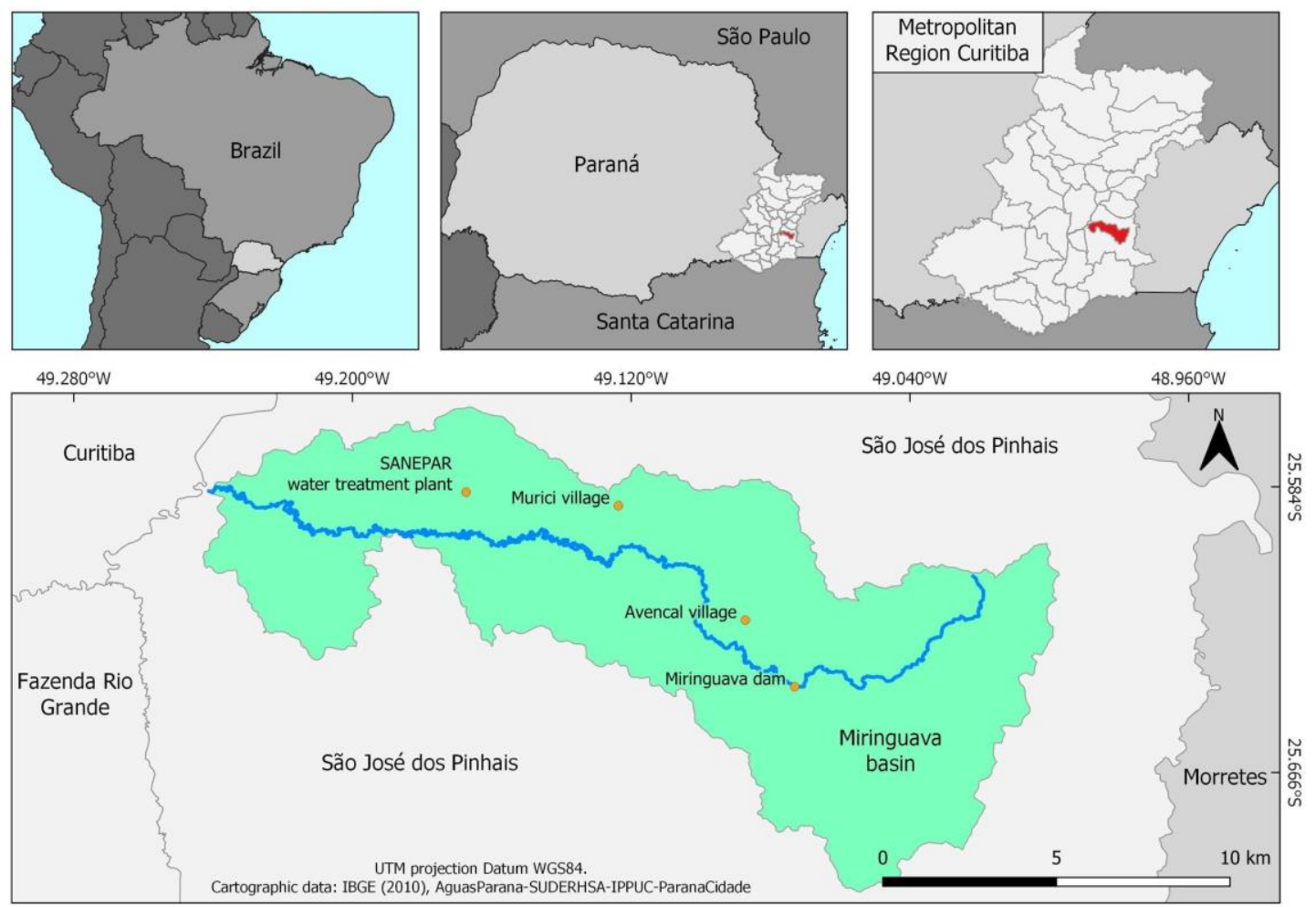

Cartographic base: IBGE (2010), AguasParaná-Suderhsa- IPPUC-Paranacidade (2000). Map credits: Tathiane Anazawa and Augusto Schmidt.

The population of SJP $(264,210)$ is made up of three-fourths white $(73 \%)$, one-fourth (23\%) pardos and $>1 \%$ are of Asian $(0.65 \%)$ and indigenous $(0.13 \%)$ origins (Ministério 
Público do Paraná, 2010). 81\% (77,286 ha) of the territory of SJP $(94,592$ ha) is rural, $13 \%$ of which $(13,510 \mathrm{ha})$ is used for agriculture.

SJP is one of the main producers of vegetables in Paraná, but with an atypical $95 \%$ of family farming. Government school lunch programs foresee the implementation of $100 \%$ organic produce until 2030, further enhancing the importance of SJP's supply function (Agência de Notícias do Paraná, 2018). Furthermore, about 50\% of its territory is committed to the "production" of water for public supply (Maia, 2017; São José dos Pinhais, 2018), raising opportunity costs for land in SJP, especially under the ongoing urbanization trends. According to Bossle (2010), urbanization increased $118 \%$ between 1980 and 2000. Until 2020, another $20 \%$ growth was expected in the area, mainly due to condominiums (COMEC, 2006). Deforestation from 2000 to 2018 amounted to 1.48 Kha of tree cover loss (-2.2\%) (Global Forest Watch, 2019).

For those reasons, state and non-state actors have been pushing for innovative conservation approaches. A national legislative framework for facilitating PES implementation (Alarcon et al., 2016), which passed as a National PES law (№ 14.119), has been promoted by various of the NGOs involved in the case study and was approved in January 2021.

Water and conservation have been on the agendas since at least the 1990s in Paraná. In this sense, the 1998 "Headwaters Law" has emphasized the importance of protecting land for securing public water supplies. In the current 2020-21 water crisis, the hope (and pressure) is high for a dam project carried out by the state water supplier Companhia de Saneamento do Paraná (SANEPAR) in the Miringuava basin to solve the problem (Agência de Notícias do Paraná, 2020; Cruz, 2020). PES has been a condition by the Environmental Institute (IAP) as a compensation measure for the concession of the dam construction.

SANEPAR, in cooperation with SEMA, is executing the PES project. The local SEMMA and Agricultural Secretariat (SEMAG) are assisted by those state actors and the NGOs Foundation Grupo Boticario (FGB), The Nature Conservancy (TNC), and the Society for Wildlife Research and Environmental Education (SPVS). Such actors have helped implement PES at different stages and levels. Furthermore, technical support comes from the Parana Center of Reference in Agroecology (CPRA), Emater and Embrapa.

The process of implementing the reservoir has been going on for more than 15 years. Responding to demands and recommendations of environmental authorities, SANEPAR has established a socio-environmental MG that promotes dialogue about socio-environmental issues linked to the construction of the dam. Its monthly meetings are the closest forum to the community and have become the main space for articulation between the commoners and the urban stakeholders. 


\section{Results and analysis}

In this section, the results for each of Ostrom's (2008) eight design principles are presented and analyzed in more detail.

\section{Principle 1: Clearly defined boundaries}

The first principle refers to the boundaries of the resource system and the clarity of those boundaries to individuals or households with rights to harvest resource units. Described as "boundary rules related to who can enter, harvest, manage, and potentially exclude others" (Ostrom, 1990, p. 91; 2008, p. 32) this principle can affect CPR users' trustworthiness and cooperation.

For the case of PES, this is a theoretical challenge for this case study since users and producers are in different territories. Corroborating this challenge, Turner (1999, p. 649) points out that policy-makers and practitioners often expect "the community" in CPR systems to be an unchangeable group of individuals who jointly manage resources following clearly defined (uncontested) rules of access. However, the reality in agro-pastoral systems diverges a lot from such an idealized model. Turner states that "[r]ules of access are often politically malleable and spatial boundaries fluid" (Turner, 1999, p. 649).

According to the actors interviewed during our fieldwork, there is a great agreement that the boundaries of private properties are clear and consolidated, and there are no reported conflicts between landowners. The only territorial and boundary conflict in the region has been sparked by the delineation of the Environmental Protection Area $\left(\mathrm{APA}^{2}\right)$ for constructing the SANEPAR dam. The delineation process resulted in a consequent dispute about which areas would qualify for PES. Those stakeholders who reported not to be familiar with the region primarily urban project managers - said they were unsure about the applicability of boundary conflicts.

There are some uncertainties about the concrete areas to be protected and that are not defined yet. This is due to the early stage of the project and the APA's boundaries, which are still being defined. While SANEPAR's official statements mention the restrictive conservation zone only upstream of the dam, the Public Prosecutor and others are reported to have discussed about the area being upstream of the catchment, causing uproars in the affected Avencal village (see figure 1), as it would then further restrict the farmers' conventional agricultural practices.

In defining the boundaries, power issues were only mentioned tangentially, as most interviewed actors refer to legally established land titles. Interviewees did not discuss if such land titles were negotiated and whether they are fair. Both the importance of those peri-urban

\footnotetext{
${ }^{2}$ APA, abreviation in Portuguese for Área de Proteção Permanente.
} 
commons and the power dynamics they are suddenly inserted into with the PES becomes clear, as the areas are under growing urbanization pressures (Garcias \& Sanches, 2009).

\section{Principle 2: Proportional equivalence between benefits and costs}

The second design principle deals with the amount of resources a user is allocated, their relation to local conditions, and the rules requiring labor, materials, and/or money inputs (Ostrom, 2008, p. 33). While this principle showed the greatest agreement among the interviewed stakeholders in our sample, the idea of "cost-benefit relation" was often cited by practitioners. However, PES cannot be seen simply as a market tool that facilitates transactions of externalities (Schomers \& Matzdorf, 2013), but it needs to be mediated between public institutions and social actors.

From a management perspective, the actors involved in the judicial and operational planning as well as in the communication of the PES arrangement, the expected long-term environmental gains are evident. These benefits are often not as clear to the local dwellers of the Miringuava basin. As these dwellers are the producers of the CPR, it is of critical to the success of the effectiveness of the PES that they see the (financial) returns of their management practices as balanced with their immediate losses as sufficient compensation for the conservation of their previously productive areas.

An interesting problem pointed out by Cox et al. (2010) as well as empirical research by Gautam \& Shivakoti (2005) is the "internal-external type of congruency", which is a significant point of dispute between the farmers of the Miringuava case and the urban administrators that suggest the application of PES from the outside. The amount paid by the PES arrangement to compensate the farmers for the loss in CPR (i.e., farmland use) is seen as disproportionate to the loss in food production. Since the farmers are tightly integrated into the food provision chains of the city, they depend on their marketable incomes from their agricultural products.

Ostrom (2008, p. 32) states that the rules must be designed in a way to "allocate benefits proportional to inputs that are required." In the case of the establishment of an operational PES arrangement, these inputs include not only the physical environmental management work but also related bureaucratic costs, the time and efforts invested in meetings, as well as the "costs on users of operating a system" (Ostrom, 2008). During our field research period, representatives of the farmers complained about the lost time and disproportionate use of time for discussing topics and rules that would not benefit them. 


\section{Principle 3: Collective choice arrangements}

Ostrom's (2008, p. 33) third principle constipates that most individuals affected by harvesting and protection rules must be included in the group that can modify these rules. This question of collective choice of the PES arrangement was evaluated very differently by stakeholders of the different spheres, hinting at the present power dynamics.

Generally, the public organs and the prominent NGO stakeholders (FGB, TNC) saw the decision-making process and the creation of process' rules as very inclusive. On the other hand, the small civil society actors have often felt confronted with the construction of the dam and the compensations of which PES is a part, and saw it as a top-down decision. Several of the interviewed stakeholders revealed, in informal conversations, that they see the decisionmaking arrangement as a small impenetrable circle of well-networked stakeholders with similar interests. Similar findings were confirmed in research on the policy network (Weins, 2019).

The focus on the term "stakeholders" has been problematized and points to a judicialization of participation processes, especially in connection to for-profit actors. In the broader context of neoliberalism in Latin America, some authors have referred to a "stakeholderization" that has emerged as a powerful governance paradigm but that has frequently been undermined by corporate interests (Alonso-Fradejas, 2018). Some corporate actors in the MRC have expressed their interest in PES which poses both theoretical and practical power issues in "greening" businesses, possibly putting the representativeness of the arrangement out of balance (Kosoy \& Corbera, 2010).

Ostrom (2008, p. 34) affirms that, in order for the third principle to apply, "individuals affected by a resource regime [should be] authorized to participate in making and modifying the rules." This statement conflicts with the reality of the interviewed stakeholders in our interviews, as the rules and procedures are not considered fair by many affected individuals. Ostrom (2008) emphasizes that "[a]s environments change over time, officials located far away do not know of the change, so being able to craft local rules is particularly important." The principle further considers the possible role of local elites (see Krott et al., 2014), as some "local common property institutions empower a local elite to make most of the collective choice decisions." In such a case, it would not be consistent with design principle two, as it could be "expect[ed] that the policies primarily benefit the elite."

The aspects brought forth by this principle strongly connect with the discussion on participation in forest governance by authors like Krott et al. (2014). Their fieldwork in Vietnam has shown the importance of collective choice and equal participation of the affected community in the rule-making process and the independence of those powerful stakeholders' rules. Other studies that discuss governance arrangements and forms of participation in peri- 
urban environments (through IAD analysis) show the complexity of this theme (Barton et al., 2017; Jiménez et al., 2019; Mackenzie \& Gibbons, 2019).

\section{Principle 4: Monitoring}

As suggested by theory, monitors who actively audit biophysical conditions and user behavior and who are accountable to the users and/or are the users themselves are central to ensuring compliance with established rules (Ostrom, 2008). The monitoring of compliance with the established CPR rules has been a focus of some of Ostrom's later work on CPR institutions (see, e.g., Ostrom \& Nagendra, 2006). Active and recognized forest users are more likely to contribute to monitoring and improve the overall conditions of the CPR (Coleman \& Steed, 2008). Ostrom suggests that "[m]ost self-organized resource regimes select their own monitors" and that in turn "[t]hese monitors are accountable to authorized users and keep an eye on resource conditions as well as on harvesting activities" (Ostrom, 2008, p. 215). With those empirically based findings, we need to seriously question the dominant rule-enforcing mentality that prevails in traditional conservation policies, and that can also be found in Brazil.

In the view of one of the interviewed representatives of an association, for monitoring compliance with PES rules, "a commission would have to be set up with representatives of various institutions, including beneficiaries." However, most $(n=8)$ interviewees responded that monitoring is still unclear to them, as the arrangement is not yet final. Only the central stakeholders more closely linked to SANEPAR and SEMA considered monitoring transparent and fair.

\section{Principle 5: Graduated sanctions}

According to theory, for a CPR system to be robust, users who violate rules in use should receive graduated sanctions from other users, officials accountable to them, or both (Ostrom, 2008, p. 33). This principle generated similarly unclear results, with roughly one-third of the actors responding yes $(n=4)$, no $(n=5)$, and unclear $(n=6)$. Among the diverse answers, positions ranged from radical exclusion upon first rule-breaking to very mild opinions on infractions. Given the relatively weak legal environmental restrictions in the peri-urban context, the general Latin American scenario of public security issues, and the rhetoric of the current political environment, sanctions and punishments were likely seen as more justified. Furthermore, considering the Brazilian judicial context, there is relatively ineffective policing of laws. Such a context involves an overall more substantial rhetorical agreement to correctness in compliance with rules than what is actually followed through in practice (Drummond \& Barros-Platiau, 2005; Silva et al., 2019). 
Initial sanctions should theoretically be "so low as to have no impact on the expected benefit-cost ratio of breaking local rules" (Ostrom, 2008, p. 35). Nevertheless, compliance is often "assumed away by analysts" who assume "all-knowing and all-powerful external authorities who enforce agreements" (Ostrom, 1990, p. 93). Some of Ostrom's originally studied cases show that a "user might break a rule in error or because of difficult problems". One of our interviewees affirmed that it depends on the seriousness of the infraction, but "if they are serious, and committed the infraction purposefully, the sanction does not have to be gradual".

\section{Principle 6: Conflict resolution mechanisms}

The sixth principle states that "Users and their officials have rapid access to low-cost local arenas to resolve conflict among users or between users and officials" (Ostrom, 2008, p. 33). Since conflict in socio-environmental issues is practically inevitable, without "available or easily accessible" conflict resolution mechanisms, successful CPR management is more difficult (Cox et al., 2010, p. 48). A local and low-cost mechanism for resolving conflicts, especially for socio-environmental ones within the studied PES arrangement, has shown to be still unclear. However, some recent developments lead us to consider that this principle might be more applicable than evaluated during the field research in 2018.

Ostrom (2008, p. 35) states that while it is possible that "participants may interpret a rule that they have jointly made in different ways", "rules must be understood in order to be effective". Arrangements for resolving conflicts must be "rapid, low cost, local arenas." Only the "Miringuava Socioenvironmental Management Group" presents such characteristics. For this reason, it was considered an essential part of the institutional dimensions of the studied PES. The Management Group's relevance was confirmed by several stakeholders, who came to accept it as an arena for issues concerning the water-food nexus. Most stakeholders who showed this opinion are regular participants of the group, understand its workings, and recognize its potentials.

Another mechanism for resolving disputes and conflicts regarding the dam (property compensations, traffic, loss of productive land), is the Public Prosecutor's Office (Ministério Público). However, it is neither rapid, nor local, nor low cost in Ostrom's terms. It has acted in defense of the population's rights, changing SANEPAR's dam construction plans according to their demands. Nevertheless, its formal bureaucracy and its distance from the locality make it unfit for resolving informal conflicts for commons dilemmas that could be resolved in an adhoc manner. 


\section{Principle 7: Minimal recognition of rights}

One aspect that influences institutional robustness is the power of external authorities to interfere in users' rights to devise their own institutions and long-term tenure rights (Ostrom, 2008). National and local governments must minimally recognize people's right to organize, which is an essential condition for establishing fair and inclusive rules for the CPR system (Ostrom, 2008).

Cox et al. (2010, p. 48) stress that "an external government agency imposing its own rules on a community managing a CPR may suffer from a government failure." An example of resource systems with great difficulties in finding such rules would be, e.g., when governmental authorities do not recognize its participants. This lack of recognition would cause the need for unanimity in decision-making, thus presenting a threat by individuals who disagree and threatening to report unrecognized systems. "When external governmental officials presume that only they can make authoritative rules, sustaining a self-organized regime is difficult" (Cox et al., 2010, p. 1). Under these principles, we consider the issue of power to be central within the arrangement as it perpetuates injustices within the current legal and landholder system, an issue that has been lamented by several of the less powerful interviewed actors.

Pagdee et al. (2006) found local authority to be associated with tenure security and violations of the seventh principle to be "associated with less successful community-based resource management regimes. Cox et al. (2010) also cite the example of a study from West Africa (Turner, 1999) in which the government's failure to recognize local knowledge and existing institutions lead to partial problems in the process.

This principle was evaluated with an affirmative tendency by half of the actors. One critical stakeholder claimed this recognition does not exist and named industrial and agroindustry lobby groups who asserted indirect pressure on farmers and their families, as these depend on distribution networks and jobs connected to them. The political setting of the 2018 Presidential Elections in Brazil, during which the fieldwork was conducted, may have influenced this issue. The then-president-elect threatened to sacrifice environmental concerns over economic development (Fearnside, 2018). Furthermore, funding cuts and open hostility towards science and environmental conservation were mirrored in the local conflict in the Miringuava basin and were politically legitimized (Escobar, 2018).

\section{Principle 8: Nested enterprises}

The eighth principle refers to the multiple layers of nested arrangements. According to Ostrom (2008, p. 36), this principle applies solely to large CPR systems. The author recognizes that "governance activities are organized in multiple layers of nested enterprises," meaning that they are part of other dimensions of governance. Larger institutions exist to govern the 
interdependencies among smaller units. Here, citing Yoder (apud Ostrom, 2008, p. 10), the allocation of water use rules "among major branches of an irrigation system" will "differ from the rules used to allocate water among farmers along a single distribution channel". "Consequently, among long-enduring self-governed regimes, smaller-scale organizations tend to be nested in ever-larger organizations" (Yoder apud Ostrom, 2008, p. 10).

While this principle was the third most positively evaluated in our study, the actual integration of the PES arrangement as a CPR system into higher-level governance is only given in the case of the integrated metropolitan water supply system (Companhia de Saneamento do Paraná, 2013; Cassilha et al., 2020). The powerful COMEC and PróMetrópole agencies have the integration of transportation and commercial agendas as their primary purpose. In our research, they showed only goodwill and presented imaginaries towards metropolitan environmental governance for the MRC. In this scenario, the PES arrangement of the Miringuava basin would be included at some point in the future.

\section{Synthesis of the results}

The analysis of the design principles is synthesized in Figure 2. The analysis shows that, while several of the principles apply to the SES in the Miringuava basin case study, favoring the PES implementation, relevant aspects of the program's management must be addressed. Several of the interviewed actors mentioned that the future concrete arrangements are likely and beneficial, as suggested in Ostrom's eighth design principle. However, the critique of this principle's power-blindness must be explored in more detail, as higher-level formal governance institutions clearly assert their influence much more forcefully on the local CPR. The theoretical discussion about ES as commons sheds light on institutional dimensions that central stakeholders and public administration may not sufficiently consider. 
Figure 2 - Evaluation of Ostrom's eight design principles for the Payments for Ecosystem Services (PES) arrangement in the Miringuava basin according to the interviewed participants

\section{Evaluation of Ostrom's 8 Design Principles}

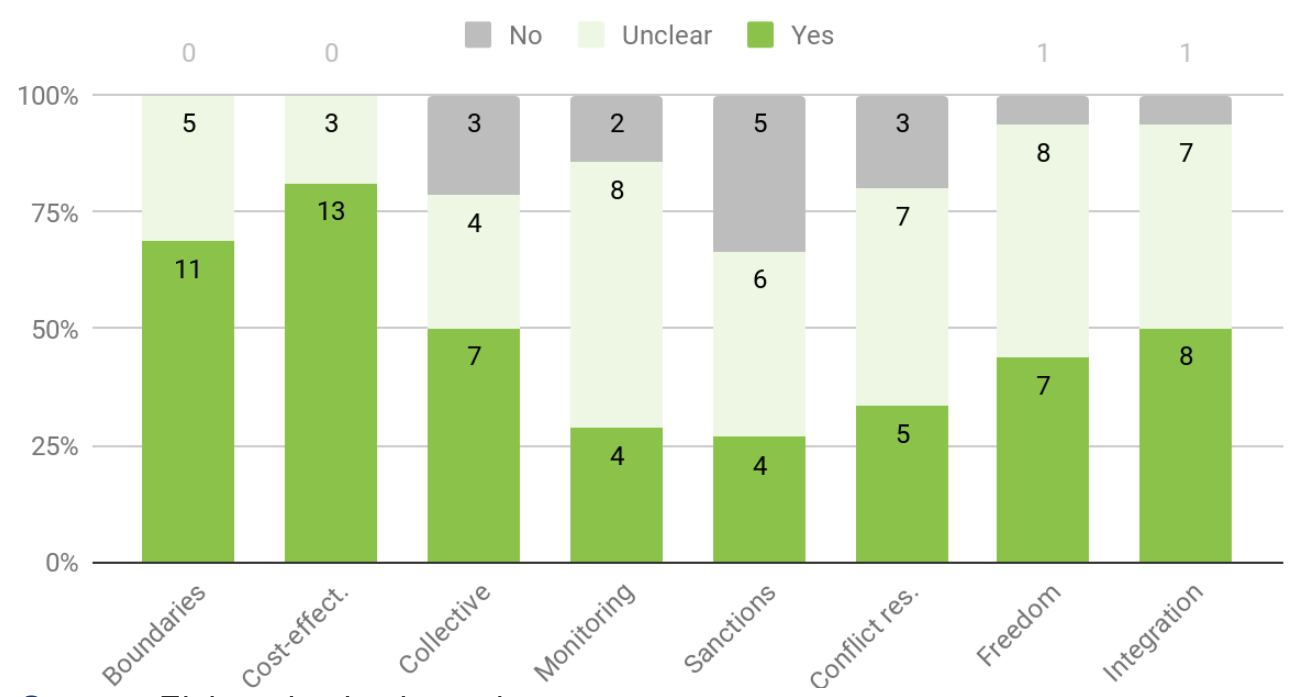

Source: Elaboration by the authors.

According to the collected data, the first five principles apply to about two-thirds, according to the actors. These first five principles are a coherent set of theoretically founded explanations for CPR systems' characteristics and organization. Ostrom (2005, p. 267) suggests that a theoretical explanation of why they may work together may be that when the users of a resource design their own rules (design principle 3) enforced by local users (principle 4) using graduated sanctions (principle 5) that clearly define who has rights to withdraw them from a well-defined resource (design principle 1) and that effectively assign costs proportionate to benefits (principle 2), collective action and monitoring problems tend to be solved in a reinforcing manner.

\section{Discussion}

The case explored here, shows important implications for CPR and ES debates in periurban contexts. When influential urban stakeholders enter the arena of formerly rural commons, power imbalances can quickly be overshadowed. The central conflict in the Miringuava PES implementation can be found in the land-use dispute between urbanization, agricultural use, and conservation (incl. organic farming). The latter issue is a priority for wellnetworked central stakeholders like SANEPAR to lower water treatment costs. However, this paradigm shift is resisted by farmers, who fear a drop and uncertainty in their income.

In our data, power issues were highlighted in the different perceptions of principle 3, showing stark differences between affected local CPR managers who felt to have no stake in the decision-making processes. Likewise, imbalances are felt among the involved 
organizations. While principle 2 was evaluated as very applicable by the prominent stakeholders, the MG meetings showed otherwise. Representatives of the farmers complained about the disproportionate use of time for discussing topics and rules that would not benefit them.

In the discussion of peri-urban commons, a reflection about the design principles promises exciting advances. PES as a public policy tool for the reapproximation of the urban periphery to the center or even an inducer of a form of metropolitan environmental governance that approaches human-nature relations and resource demands beyond paradigms of purely "urban" demanders and "rural" providers, could help to break this dualistic logic of rural-urban relations (Allen, 2003; Gutman, 2007; Azzulin et al., 2019).

While the established MG could eventually serve as a conflict resolution mechanism (principle 6), it is still not equally accepted by the affected population. Most likely, this is due to its recent creation by the most influential stakeholder in the process (SANEPAR). The MG resolved other issues and only gradually moved towards topics of interest to local communities when under consistent pressures to do so. Indeed, trust-building has not been approached in the best way possible in this case. The recent contracting of a socio-environmental management company to accompany the community's issues has been a step in the right direction, but it will take time to establish those relations. Within the short-term contractual logic of those public licitations, it is challenging to establish long-lasting relations.

During our field research (March-November 2018), we identified that the stakeholders' social organization involving SANEPAR has led to the formalization of the management group, which might put some smaller interest groups at a disadvantage. The (few) expropriated landowners represented by the relatively broad-interest association ASSOPAM $^{3}$ continue to participate in the organization process and dialogue about the CPRs in the MG. They share views about the formalization of a basin committee to articulate and eventually balance disputes (Medeiros, 2011, Cassilha et al., 2020), even though some are discontent with the slow progress. Such steps, following the Theory of the Commons and the literature on the social dimensions of ES, could be followed through a more robust institutional arrangement.

While PES is a practical tool for recognizing the importance of peri-urban commons and introducing a market logic to ES provision, it also brings the danger of distorting management choices. If not mediated adequately by state actors who guarantee democratic representation, stronger cooperations with third sector actors with knowledge and network advantages can easily exclude local commoners. This process could lead to the agriculturist population's opposition to conservation and environmentally less harmful techniques, instead of contributing to sustainable management of the basin. The dispute about pesticide use has

${ }^{3}$ Landowners, Residents, Breeders \& Farmers Association of the Miringuava River Basin of SJP (ASSOPAM) 
shown that locals often support anti-environmentalist positions that are now contrary to strategic decision-making at higher and central levels of municipal and state governance.

\section{Conclusions}

For effective CPR management, effective participation of all affected stakeholders is needed to consolidate collective action for their sustainable use. Multi-level arenas can help mediate different interests and needs if all participants trust the processes. If not, they risk exacerbating existing conflicts.

As the analyses of our case study have shown, PES needs to be mediated fairly by the state to enable stable local institutional arrangements. The role of the public (and civil society) needs to be clearly defined and judicially guaranteed to make sure that conservation policies serve societal interests and do not suffer alteration from special interest groups. The considerable lack of technical knowledge by the small municipal administrative bodies is compensated for with strong cooperation with the third sector. Herein lies a significant risk in the in- and exclusion of factors that are (in)convenient to those stakeholders who provide the information and technical knowledge those public policies are built on.

In the ongoing PES implementation, the socio-environmental follow-up is on a good way to include the factors that had largely been disregarded in the central actors' planning phase. The inclusion of the local population who "lives off the land" in the planning process during the field research period has made clear how the issues on the political agenda significantly differ from those on the ground. This imposition of rules and restrictions on those farmers without including their views, lifestyles and needs still should be debated. With few job alternatives, the farmers see their existence as threatened by environmental actors who are perceived as outsiders with the power to overrule them. Given this situation, it is unlikely that those individuals will adhere to rules defined outside of their interest sphere, a problem discussed broadly in commons theory. It can thus be said that a PES, which was created to mediate conflicts, may become a source of conflict and exacerbate unjustified power over livelihoods in the peri-urban territory.

Combined analysis of the principles of robustness in this PES situation led us to some reflections and allowed us to answer to what extent PES can be considered a tool for inducing collective action in peri-urban commons. In this sense, we conclude that: (1) the commons are, above all, the ES in themselves; thus, we are proposing a reflection on the socio-ecological complexity of systems in which PES is inserted; (2) by adding market aspects into this discussion, PES becomes a collective action problem; and (3) this context may imply that PES is, therefore, a possibility of a mechanism to promote the materialization of greater robustness 
of peri-urban commons institutions as a tool for inducing local management of peri-urban commons.

In this regard, we understand that a structure of greater symmetry among engaged agents in ES supply and demand relations is essential. Neither state agents per se nor the market seem to be proper governance structures to mediate and/or host complex interactions among beneficiaries and users of SE. Therefore, innovation in these arenas of situated action is needed.

Here, we point out two main limitations of this research that indicate potential priorities for future research. Firstly, it was not possible to handle hybrid aspects of ES as CPR, especially concerning private property rights and peri-urban environment complexity. Therefore, we endorse more profound studies on PES contexts regarding even higher complexities of combined ecosystems and sociopolitical systems. Secondly, further discussions on how and to what extent socio-environmental challenges (acting in synergy in peri-urban regions and given particular local rural-urban dynamics) influence vulnerability and resilience in PES systems. Certainly, these studies may highlight important human dimensions treated here in a preliminary approach. In any case, we affirm the experience considered in the development of this research. Its contributions to commons theory are vital to expand understanding of PES not only as an economic tool but as an outcome of negotiation processes in collective action contexts.

\section{Acknowledgements}

This research was carried out with the support of the Coordination for the Improvement of Higher Education Staff - Brazil (CAPES) - Funding Codes 001, 1702546, 1702424, and 88887.356469/2019-00 and the São Paulo Research Foundation (FAPESP) № 2019/035810 .

\section{References}

Adeoti, O. (2019). Understanding the factors constraining the implementation of watershed management in Nigeria. Sustain. Water Resour. Manag. 5(4), 2001-2021 https://doi.org/10.1007/s40899-019-00353-y.

Afroz, S., Cramb, R. \& Grunbuhel, C. (2016). Collective Management of Water Resources in Coastal Bangladesh: Formal and Substantive Approaches. Hum Ecol 44, 17-31. https://link.springer.com/content/pdf/10.1007/s10745-016-9809-x.pdf.

Agência de Notícias do Paraná. (2014, March $3^{\text {rd }}$ ). Paraná é o estado mais avançado na política de recursos hídricos. Retrieved on October $1^{\text {st }}, 2020$, from http://www.aen.pr.gov.br/modules/noticias/article.php?storyid=79568. 
Agência de Notícias do Paraná. (2018, October 19th). Estudo propõe 100\% de orgânicos na merenda escolar. Retrieved on October $1^{\text {st }}, 2020$ from

http://www.aen.pr.gov.br/modules/noticias/article.php?storyid=99232\&tit=Estudo-propoe100-de-organicos-na-merenda-escolar.

Agência de Notícias do Paraná. (2020, September 21 th). Governo e Fundação Boticário anunciam ação para melhorar a qualidade da água na RMC. Retrieved on October $1^{\text {st }}$, 2020 from http://www.aen.pr.gov.br/modules/noticias/article.php?storyid=108885.

Allen, A. (2003). Environmental planning and management of the peri-urban interface: perspectives on an emerging field. Environment and Urbanization, 15(1), 135-147. https://doi.org/10.1630/095624703101286402.

Alarcon, G. G., de Freitas, L. A. dos S., da Fountoura, G. O., de Macedo, C. X., \& Ribeiro, D. C. (2016). The challenges of implementing a legal framework for Payment for Ecosystem Services in Santa Catarina, Brazil. Natureza \& Conservação, 4(2), 3-7. https://doi.org/http://dx.doi.org/10.1016/j.ncon.2016.05.003.

Alonso-Fradejas, A. (2018, April ${ }^{\text {rd }}$ ). 'Authoritarian corpopulism' supports the rise of sugarcane and oil palm agribusinesses in Guatemala. Open Democracy.

https://www.opendemocracy.net/en/authoritarian-corpopulism-supports-rise-of-sugarcaneand-oil-palm-agribusine/.

Azzulin, M. B., Centurion, N., Weins, N. W., Gadda, T. M. C., \& Garcias, C. M. (2019). A influência de instrumentos de políticas públicas para a conservação. Guaju, 5(2), 3-14. https://doi.org/http://dx.doi.org/10.5380/guaju.v5i2.

Bakker, K. (2009). The "Commons" Versus the "Commodity": Alter-Globalization, AntiPrivatization and the Human Right to Water in the Global South. Privatization: Property and the Remaking of Nature-Society Relations, 38-63.

https://doi.org/10.1002/9781444306750.ch2.

Bardhan, P. (2000). Irrigation and Cooperation: An Empirical Analysis of 48 Irrigation Communities in South India. Economic Development and Cultural Change, 48(4), 847865. http://doi.org/10.1086/452480.

Bardin, L. (2011). Análise de Conteúdo (3 $3^{\text {rd }}$ ed.). São Paulo: Edições 70.

Barton, D. N., Benavides, K., Chacon-Cascante, A., Le Coq, J.-F., Quiros, M. M., Porras, I., Ring, I. (2017). Payments for Ecosystem Services as a Policy Mix: Demonstrating the institutional analysis and development framework on conservation policy instruments. Environmental Policy and Governance, 27(5), 404-421. https://doi.org/10.1002/eet.1769.

Berbés-Blázquez, M., González, J. A., \& Pascual, U. (2016). Towards an ecosystem services approach that addresses social power relations. Current Opinion in Environmental Sustainability, 19. https://doi.org/10.1016/j.cosust.2016.02.003.

Berkes, F. (2006). From community-based resource management to complex systems: the scale issue and marine commons. Ecology and Society 11(1). https://www.ecologyandsociety.org/vol11/iss1/art45/.

Bossle, R. C. (2010). Gestão do Uso e Ocupação do Solo: Estudo de Caso da Bacia do Rio Miringuava, São José dos Pinhais, Paraná. [Doctoral thesis, Universidade Federal do Paraná]. https://bit.ly/2STVViO. 
Cassilha, S. do A., Gadda, T. M. C., Schmidt, A. F. J., \& Weins, N. W. (2020). The role of subnational institutions in adhering to the water integration agenda - lessons from metropolitan water governance in Curitiba. CIDADES, Comunidades e Territórios, 40(Jun), 200-218. https://doi.org/10.15847/cct.jun2020.040.art05.

Castro, F. (2017). Position Paper The Commons in Latin America. CEDLA Centre for Latin American Research and Documentation LASP Latin American Studies Programme. http://www.cedla.uva.nl/CO_LAB/PDF/Position_Paper-LA\%20Commons_Co_Lab.pdf.

Clement, M. T. (2010). Urbanization and the Natural Environment: An Environmental Sociological Review and Synthesis. Organization \& Environment, 23(3), 291-314. https://doi.org/10.1177/1086026610382621.

Coleman, E. A., \& Steed, B. C. (2009). Monitoring and sanctioning in the commons: An application to forestry. Ecological Economics, 68(7), 2106-2113.

https://doi.org/10.1016/j.ecolecon.2009.02.006.

Companhia de Saneamento do Paraná. (2013). Plano Diretor SAIC: Sistema de Abastecimento de Água Integrado de Curitiba e Região Metropolitana. Curitiba. Retrieved from http://site.sanepar.com.br/arquivos/saicplanodiretor.pdf in December 2018.

Coordenação da Região Metropolitana de Curitiba. (2006). Plano de Desenvolvimento Integrado da Região Metropolitana de Curitiba: propostas de ordenamento territorial e novo arranjo institucional. Curitiba. Retrieved from

http://www.comec.pr.gov.br/arquivos/File/PDI_2006.pdf in December 2018.

Coordenação da Região Metropolitana de Curitiba. (2017). Região metropolitana de Curitiba. Revista Da Região Metropolitana de Curitiba, 2, 90. Retrieved from http://www.comec.pr.gov.br/arquivos/File/RMC/Revista_fev_2017.pdf in December 2018.

Corbera, E., Kosoy, N., \& Martínez Tuna, M. (2007). Equity implications of marketing ecosystem services in protected areas and rural communities: Case studies from MesoAmerica. Global Environmental Change, 17(3-4), 365-380.

https://doi.org/10.1016/j.gloenvcha.2006.12.005.

Cox, M., Arnold, G., \& Villamayor, S. (2010). A Review of Design Principles for Communitybased Natural Resource Management. Ecology and Society, 15(4), 38. http://www.ecologyandsociety.org/vol15/iss4/art38/.

Cruz, E. (2020, September $\left.13^{\text {th }}\right)$. Curitiba e RMC vão ter rodízio mais duro se reservatórios caírem a 25\%. Gazeta do Povo. https://www.gazetadopovo.com.br/parana/curitiba-e-rmcvao-ter-rodizio-mais-duro-se-reservatorios-cairem-a-25/.

Drummond, J., \& Barros-Platiau, A. F. (2005). Brazilian Environmental Laws and Policies, 1934-2002: A Critical Overview. Law and Policy, 28(1), 83-108.

https://doi.org/10.1111/j.1467-9930.2005.00218.x.

Ernstson, H. (2013). The social production of ecosystem services: A framework for studying environmental justice and ecological complexity in urbanized landscapes. Landscape and Urban Planning, 109(1), 7-17. https://doi.org/10.1016/j.landurbplan.2012.10.005.

Escobar, H. (2018, October 19 $\left.{ }^{\text {th }}\right)$. Scientists, environmentalists brace for Brazil's right turn. Science. https://doi.org/10.1126/science.362.6412.273. 
Fearnside, P. (2018, November $\left.8^{\text {th }}\right)$. Why Brazil's New President Poses an Unprecedented Threat to the Amazon. Yale Environment 360 / Yale School of Forestry \& Environmental Studies, Nov(8). https://e360.yale.edu/features/why-brazils-new-president-poses-anunprecedented-threat-to-the-amazon.

Ferreira, L. C., Barbi, F. \& Barbieri, M. D. (Eds). (2020). Dimensões humanas das mudanças climáticas no Sul Global. Curitiba: Editora CRV. https://doi.org/10.24824/978655578415.2.

Garcias, C. M., \& Sanches, A. M. (2009). Vulnerabilidades sócioambientais e as disponibilidades hídricas urbanas: levantamento teórico-conceitual e análise aplicada à região metropolitana de Curitiba - PR. Risco: Revista de Pesquisa Em Arquitetura e Urbanismo (Online), 10, 96-111. https://doi.org/10.11606/issn.1984-4506.v0i10p96-111.

Gautam, A. P., \& Shivakoti, G. P. (2005). Conditions for Successful Local Collective Action in Forestry: Some Evidence From the Hills of Nepal. Society \& Natural Resources, 18(2), 153-171. https://doi.org/10.1080/08941920590894534.

Global Forest Watch. (2018). Tree cover loss in São José dos Pinhais. Retrieved on October $10^{\text {th }}, 2018$ from http://bit.ly/2TiahbS.

Gómez-Baggethun, E., \& Muradian, R. (2015). In markets we trust? Setting the boundaries of Market-Based Instruments in ecosystem services governance. Ecological Economics, 117, 217-224. https://doi.org/10.1016/j.ecolecon.2015.03.016.

Gutman, P. (2007). Ecosystem services: Foundations for a new rural-urban compact. Ecological Economics, 62(3-4), 383-387. https://doi.org/10.1016/j.ecolecon.2007.02.027.

Harrel, M. C. \& Bradley, M. A. (2009). Data Collection Methods: Semi-Structured Interviews and Focus Groups. Rand Corporation.

https://www.rand.org/pubs/technical_reports/TR718.html.

Hausknost, D., Grima, N., \& Singh, S. J. (2017). The political dimensions of Payments for Ecosystem Services (PES): Cascade or stairway? Ecological Economics, 131, 109-118. https://doi.org/10.1016/j.ecolecon.2016.08.024.

Jiménez, A., LeDeunff, H., Giné, R., Sjödin, J., Cronk, R., Murad, S., Takane, M., Bartram, J. (2019). The Enabling Environment for Participation in Water and Sanitation: A Conceptual Framework. Water, 11(2), 308. https://doi.org/10.3390/w11020308.

Kolinjivadi, V., Adamowski, J., \& Kosoy, N. (2014). Recasting payments for ecosystem services (PES) in water resource management: A novel institutional approach. Ecosystem Services, 10, 144-154. https://doi.org/10.1016/j.ecoser.2014.08.008.

Kosoy, N., \& Corbera, E. (2010). Payments for ecosystem services as commodity fetishism. Ecological Economics, 69(6), 1228-1236. https://doi.org/10.1016/j.ecolecon.2009.11.002.

Krott, M., Bader, A., Schusser, C., Devkota, R., Maryudi, A., Giessen, L., \& Aurenhammer, H. (2014). Actor-centred power: The driving force in decentralised community based forest governance. Forest Policy and Economics, 49, 34-42.

https://doi.org/10.1016/j.forpol.2013.04.012.

MacKenzie, A., \& Gibbons, P. (2019). Enhancing Biodiversity in Urban Green Space; An Exploration of the IAD Framework Applied to Ecologically Mature Trees. Urban Science, 3(4), 103. https://doi.org/10.3390/urbansci3040103. 
Macnaghten, P. (2017). Focus groups as anticipatory methodology. In R. S. Barbour \& D. L. Morgan (Eds.), A New Era in Focus Group Research: Challenges, Innovation and Practice (pp. 343-363). London: Palgrave Macmillan UK. https://doi.org/10.1057/978-1-137-586148_16.

Maia, D. M. J. (2017). Educação e Intervenção Ambiental na Implantação da Barragem do Miringuava - Relato de Experiência. In Anais do XVI EPEA, 1-4. Curitiba: Setor de Educação da UFPR. http://www.epea2017.ufpr.br/wp-content/uploads/2017/05/524-E6S2-EDUCAÇÃO-E-INTERVENÇÃO-AMBIENTAL.pdf.

McGinnis, M. D.; Ostrom, E. (2014). Social-ecological system framework: initial changes and continuing challenges. Ecology and Society 19(2): 30. https://www.ecologyandsociety.org/vol19/iss2/art30/.

Medeiros, P. C. (2011). Relações de Poder e Resistência na Gestão Territorial das Bacias Hidrográficas no Estado do Paraná. [Doctoral Thesis, Universidade Federal do Paraná]. https://acervodigital.ufpr.br/handle/1884/26710?show=full.

Ministério Público do Paraná. (2010). Tabela 3175 - População residente, por cor ou raça. Retrieved in Octber 2018 from https://direito.mppr.mp.br/arquivos/File/20maiores.pdf.

Mundoli, S., Manjunath, B. \& Nagendra, H. (2015). Effects of Urbanisation on the Use of Lakes as Commons in the Peri-Urban Interface of Bengaluru, India. International Journal of Urban Sustainable Development 7(1), 89-108.

http://www.tandfonline.com/doi/abs/10.1080/19463138.2014.982124.

Ostrom, E., \& Nagendra, H. (2006). Insights on linking forests, trees, and people from the air, on the ground, and in the laboratory. Proceedings of the National Academy of Sciences, 103(51), 19224-19231. https://doi.org/10.1073/pnas.0607962103.

Ostrom, E.; Gardner, R. \& Walker, J. M. (1994). Rules, Games, and Common-Pool Resources. Ann Arbor. MI: University of Michigan Press.

Ostrom, E. (1990). Governing the Commons: The Evolution of Institutions for Collective Action. Political Economy of Institutions and Decisions (2003 ${ }^{\text {rd }}$ ed.). Cambridge: Cambridge University Press. https://doi.org/10.1017/CBO9780511807763.

Ostrom, E. (1999). Self-governance and forest resources. Occasional Paper, n. 20, CIFOR, Bogor, Indonesia. http://www.cifor.org/library/536/self-governance-and-forest-resources/.

Ostrom, E. E., Dietz, T. E., Dolsak, N., Stern, P. C., Stonich, S. E., Weber, E. U., ... Weber, E. U. (2002). The Drama of the Commons. Washington D.C.: National Academy Press. https://doi.org/10.17226/10287.

Ostrom, E. (2005). Understanding Institutional Diversity. Public Choice (Vol. 132). Princeton: Princeton University Press. https://doi.org/10.1007/s11127-007-9157-x.

Ostrom, E. (2008). Design Principles of Robust Property-Rights Institutions: What Have We Learned? Workshop in Political Theory and Policy Analysis, 1-28. http://ssrn.com/abstract=1304708.

Pagdee, A., Kim, Y., \& Daugherty, P. J. (2006). What Makes Community Forest Management Successful: A Meta-Study From Community Forests Throughout the World. Society \& Natural Resources, 19(1), 33-52. https://doi.org/10.1080/08941920500323260. 
Partelow, S., \& Winkler, K. J. (2016). Interlinking ecosystem services and Ostrom's framework through orientation in sustainability research. Ecology and Society, 21(3), art27. https://doi.org/10.5751/ES-08524-210327

Paudyal, K., Baral, H., \& Keenan, R. J. (2016). Local actions for the common good: Can the application of the ecosystem services concept generate improved societal outcomes from natural resource management? Land Use Policy, 56, 327-332.

https://doi.org/10.1016/j.landusepol.2015.11.010.

São José dos Pinhais. (2018). Atlas de São José dos Pinhais. São José dos Pinhais. Retrieved from http://www.sjp.pr.gov.br/wp-content/uploads/2018/05/Apresentação-doAtlas-de-São-josé-dos-Pinhais-Completo.pdf in December 2018.

Schomers, S., \& Matzdorf, B. (2013). Payments for ecosystem services: A review and comparison of developing and industrialized countries. Ecosystem Services, 6, 16-30. https://doi.org/10.1016/j.ecoser.2013.01.002.

Schröter, M., van der Zanden, E. H., van Oudenhoven, A. P. E., Remme, R. P., SernaChavez, H. M., de Groot, R. S., \& Opdam, P. (2014). Ecosystem Services as a Contested Concept: A Synthesis of Critique and Counter-Arguments. Conservation Letters, 7(6), 514-523. https://doi.org/10.1111/conl.12091.

Silva, C. L., Weins, N., \& Potinkara, M. (2019). Formalizing the informal? A perspective on informal waste management in the BRICS through the lens of institutional economics. Waste Management, 99, 79-89. https://doi.org/10.1016/j.wasman.2019.08.023.

SOS Mata Atlântica. (2018). Atlas dos Remanescentes Florestais da Mata Atlântica Mapeamento dos Sistemas Costeiros - 2018. Retrieved in October 2018 from http://mapas.sosma.org.br/.

Turner, M. D. (1999). Conflict, Environmental Change, and Social Institutions in Dryland Africa: Limitations of the Community Resource Management Approach. Society \& Natural Resources, 12(7), 643-657. https://doi.org/10.1080/089419299279362.

Watson, V. (2009). “'The Planned City Sweeps the Poor Away...': Urban Planning and $21^{\text {st }}$ Century Urbanisation." Progress in Planning 72(3):151-93.

Weins, N. W. (2019). Institutional arrangements in payments for ecosystem services: the case of the Miringuava basin in the metropolitan region of Curitiba. [Masters thesis, Federal University of Technology - Paraná].

http://repositorio.utfpr.edu.br/jspui/handle/1/4180.

Wunder, S. (2015). Revisiting the concept of payments for environmental services. Ecological Economics, 117, 234-243. https://doi.org/10.1016/j.ecolecon.2014.08.016.

Zanella, M. A., Schleyer, C., \& Speelman, S. (2014). Why do farmers join Payments for Ecosystem Services (PES) schemes? An Assessment of PES water scheme participation in Brazil. Ecological Economics, 105, 166-176.

https://doi.org/10.1016/j.ecolecon.2014.06.004. 